OPEN ACCESS

Edited by:

Che-Pei Kung,

Washington University in St. Louis,

United States

Reviewed by:

Dragana Nikitovic,

University of Crete, Greece

Sanjeev Das,

National Institute of Immunology (NII),

India

*Correspondence:

Narendra Wajapeyee

narendra.wajapeyee@yale.edu

Specialty section:

This article was submitted to

Cancer Endocrinology,

a section of the journal

Frontiers in Endocrinology

Received: 21 December 2017 Accepted: 03 August 2018

Published: 24 August 2018

Citation:

Nagarajan A, Malvi P and Wajapeyee N (2018) Heparan Sulfate and Heparan Sulfate Proteoglycans in

Cancer Initiation and Progression.

Front. Endocrinol. 9:483.

doi: 10.3389/fendo.2018.00483

\section{Heparan Sulfate and Heparan Sulfate Proteoglycans in Cancer Initiation and Progression}

\author{
Arvindhan Nagarajan ${ }^{1}$, Parmanand Malvi ${ }^{1}$ and Narendra Wajapeyee ${ }^{1,2 *}$ \\ ${ }^{1}$ Department of Pathology, Yale University School of Medicine, New Haven, CT, United States, ${ }^{2}$ Yale Cancer Center, Yale \\ University School of Medicine, New Haven, CT, United States
}

Heparan sulfate $(H S)$ are complex unbranched carbohydrate chains that are heavily modified by sulfate and exist either conjugated to proteins or as free, unconjugated chains. Proteins with covalently bound Heparan sulfate chains are termed Heparan Sulfate Proteoglycans (HSPGs). Both HS and HSPGs bind to various growth factors and act as co-receptors for different cell surface receptors. They also modulate the dynamics and kinetics of various ligand-receptor interactions, which in turn can influence the duration and potency of the signaling. HS and HSPGs have also been shown to exert a structural role as a component of the extracellular matrix, thereby altering processes such as cell adhesion, immune cell infiltration and angiogenesis. Previous studies have shown that HS are deregulated in a variety of solid tumors and hematological malignancies and regulate key aspects of cancer initiation and progression. HS deregulation in cancer can occur as a result of changes in the level of HSPGs or due to changes in the levels of HS biosynthesis and remodeling enzymes. Here, we describe the major cell-autonomous (proliferation, apoptosis/senescence and differentiation) and cell-nonautonomous (angiogenesis, immune evasion, and matrix remodeling) roles of HS and HSPGs in cancer. Finally, we discuss therapeutic opportunities for targeting deregulated HS biosynthesis and HSPGs as a strategy for cancer treatment.

Keywords: heparan sulfate, heparan sulfate proteoglycans, cancer, immune evasion, signaling

\section{INTRODUCTION}

Normal cells acquire series of genetic and epigenetic aberrations to become cancerous. The acquired cancer growth and progression enabling attributes are collectively referred to as hallmarks of cancer (1). Several hallmarks of cancer, such as sustained growth signaling, suppression of apoptosis, deregulated metabolism, immune evasion and angiogenesis can also be enhanced through pathological alterations of normal physiological processes (1).

Heparan sulfates (HS) are unbranched chains of disaccharide repeats that are heavily sulfated at various positions on their sugar residues $(2,3)$. HS can occur either conjugated to amino acids, creating heparan sulfate proteoglycans (HSPGs), or as unconjugated chains (4). Both HS and HSPGs play important roles in cancer initiation and progression. Previous studies have implicated 
the role of HS and HSPGs in several types of solid tumors as well as hematological malignancies (5-11).

HSPGs are complex biopolymers whose synthesis is orchestrated by many enzymes, which catalyze the various steps of HS synthesis with very little redundancy (Figure 1). The majority of HS deregulation in cancer occurs due to alterations in the expression of HS-synthesizing and HSmodifying enzymes, however, alterations in HSPGs can also contribute to HS deregulation (12) (also see Table 1) (10, 11, 13-84).

In this review, we provide an overview of the cell-autonomous and cell-non-autonomous roles of HS and HSPGs in cancer initiation and progression. In addition, we will also discuss opportunities to develop cancer therapies by targeting the HS and HSPG axis.

\section{CELL-AUTONOMOUS ROLE OF HS AND HSPGS IN CANCER INITIATION AND PROGRESSION}

HS and HSPGs regulate diverse cell-autonomous functions, including oncogenic signaling, apoptosis, and cellular differentiation. In this section, we describe the cell-autonomous functions of HS and HSPGs in cancer initiation and progression.

\section{Growth Factor Signaling and Regulation of Proliferation}

Previous studies have shown important roles of HS and HSPGs in oncogenic signaling (85-88). In this regard, FGF binding interactions are best characterized by the role of HS in altered Receptor Tyrosine Kinase (RTK) signaling. For example, HSmodified HSPGs bind FGF ligands and receptors to form a ternary complex and enhance signaling by promoting FGF receptor (FGFR) dimerization (89-91). This in turn results in receptor activation and enhanced FGFR signaling, which consequentially promotes tumor growth (89-91). In addition to FGF, HS binds to several different mitogenic growth factors such as PDGF, Heparin-Binding Epidermal Growth Factor-like Growth Factor (HB-EGF), and Hepatocyte Growth Factor (HGF) and modulates their signaling in a context dependent manner (86).

Breast cancer cells are also shown to overexpress HSPGs, such as Glypican 1 (GPC1) and Syndecan 1 (SDC1), which enhance the proliferative response after treatment with various growth factors due to prolonged signaling (86). Similar to breast cancer, GPC1 also has been shown to have growthpromoting effects in pancreatic cancer and gliomas $(49,92,93)$. Collectively, these studies highlight wide-spread deregulation of HSPGs in different cancers that exert tumor promoting roles.

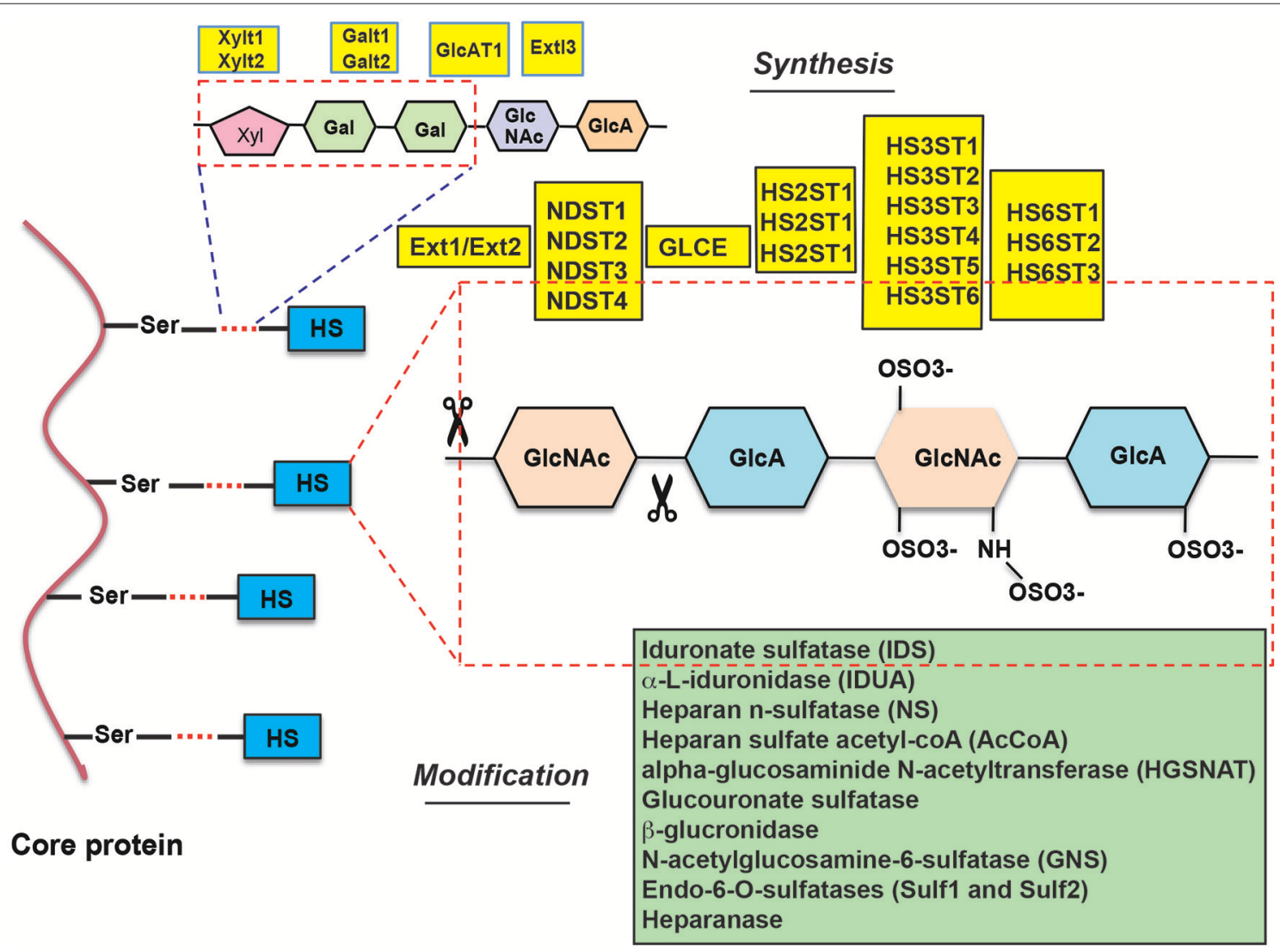

FIGURE 1 | Overview of the enzymes involved in heparan sulfate synthesis and modification. 
TABLE 1 | Deregulation of HS and HSPGs and enzymes involved in HSPG metabolism in cancer.

\begin{tabular}{|c|c|c|c|}
\hline & $\begin{array}{l}\text { Alteration in } \\
\text { cancer }\end{array}$ & Functional consequence(s) & Cancer type(s) \\
\hline \multicolumn{4}{|c|}{ Enzyme involved in HSPG metabolism } \\
\hline HS2ST1 & Upregulated & $\begin{array}{l}\text { Promote cell proliferation, invasion } \\
\text { and growth factor signaling }\end{array}$ & Prostate cancer (13) \\
\hline HS3ST2 & $\begin{array}{l}\text { Epigenetic } \\
\text { silencing }\end{array}$ & $\begin{array}{l}\text { Suppression of tumor growth and } \\
\text { invasion }\end{array}$ & Lung cancer (14) \\
\hline HS3ST2 & Upregulated & Invasion and migration & Breast cancer (15) \\
\hline HS3ST3B1 and HS3ST4 & Upregulated & $\begin{array}{l}\text { Promote cell proliferation, } \\
\text { invasiveness, and tumor angiogenesis }\end{array}$ & $\begin{array}{l}\text { acute myeloid leukemia (16) } \\
\text { Colorectal cancer (17) } \\
\text { Pancreatic cancer (18) }\end{array}$ \\
\hline HS6ST1 and HS6ST2 & Upregulated & Increased tumor Angiogenesis & Ovarian cancer (19) \\
\hline HS6ST2 & Upregulated & Poor survival of patients & Colorectal cancer (20) \\
\hline HS6ST2 & Upregulated & Bone metastasis & Breast cancer (21) \\
\hline HPSE & Upregulated & Tumor metastasis and angiogenesis & $\begin{array}{l}\text { Neuroblastoma (22), breast cancer (23), prostate cancer } \\
\text { (24), colon cancer (25), lung cancer (26), liver cancer } \\
\text { (27), ovarian cancer (28), and pancreatic cancer (29), } \\
\text { human myeloma (30) }\end{array}$ \\
\hline NDST1 and NDST2 & Upregulated & Tumor progression & Hepatocellular carcinoma (31) \\
\hline SULF1 & Downregulated & $\begin{array}{l}\text { Suppress tumor cell proliferation and } \\
\text { invasion }\end{array}$ & $\begin{array}{l}\text { Breast cancer, Pancreatic, Ovarian and head and neck } \\
\text { cancers (32) } \\
\text { Hepatocellular carcinoma (33) }\end{array}$ \\
\hline SULF2 & Unaltered & Tumor progression & Hepatocellular carcinoma and glioblastoma (34) \\
\hline SULF2 & Upregulated & Tumor growth & Hepatocellular carcinoma $(33,35,36)$ \\
\hline \multicolumn{4}{|l|}{ HSPG } \\
\hline Agrin & Elevated & Angiogenesis & $\begin{array}{l}\text { Hepatocellular carcinoma }(37,38) \text {, glioblastoma (39), } \\
\text { cholangiocarcinoma }(37)\end{array}$ \\
\hline CD44 & Elevated & Adhesion, invasion, cancer stem cell & $\begin{array}{l}\text { Breast cancer (40), colorectal cancer (41), oral } \\
\text { squamous cell carcinoma (42), melanoma (43) } \\
\text { Neuroblastoma (44) }\end{array}$ \\
\hline Collagen XVIII & Reduced & Angiogenesis & Cutaneous squamous cell carcinoma $(45,46)$ \\
\hline GPC1 & Elevated & Proliferation & $\begin{array}{l}\text { Breast cancer (47), pancreatic ductal adenocarcinoma } \\
\text { (48), glioma (49) }\end{array}$ \\
\hline GPC3 & Elevated & Proliferation & $\begin{array}{l}\text { Hepatocellular carcinoma (50), follicular thyroid cancer } \\
\text { (51), testicular germ cell tumor, neuroblastoma (52), } \\
\text { Wilms' tumor (53), yolk sac tumor (54), lung squamous } \\
\text { cell carcinoma (55), hepatoblastoma (56) }\end{array}$ \\
\hline \multirow[t]{2}{*}{ GPC5 } & Elevated & Proliferation, invasion & Rhabdomyosarcoma (10), non-small cell lung cancer (57) \\
\hline & Reduced & Initiation & Non-small cell lung cancer (58) \\
\hline Perlecan & Elevated & Proliferation, angiogenesis & $\begin{array}{l}\text { Prostate cancer (59), hepatoblastoma (60), pancreatic } \\
\text { ductal adenocarcinoma (61), melanoma (62) }\end{array}$ \\
\hline SDC1 & Elevated & Proliferation & $\begin{array}{l}\text { Breast cancer (63), pancreatic ductal adenocarcinoma } \\
(64) \text {, ovarian cancer (65), multiple myelom (66) }\end{array}$ \\
\hline SDC2 & Elevated & Adhesion, proliferation & $\begin{array}{l}\text { Breast cancer (67), prostate cancer (68), colorectal } \\
\text { cancer (69), bladder cancer (70), glioma (71), sarcoma } \\
\text { (72) }\end{array}$ \\
\hline SDC3 & Elevated & $\begin{array}{l}\text { Perineural invasion and poor } \\
\text { prognosis }\end{array}$ & Pancreatic ductal adenocarcinoma (73) \\
\hline SDC4 & Reduced & Differentiation & Neuroblastoma (11) \\
\hline \multirow[t]{2}{*}{ TbRIII } & Elevated & Migration, proliferation & Colon cancer (74), non-Hodgkin's Iymphoma (75), \\
\hline & Reduced & $\begin{array}{l}\text { Invasion, proliferation, differentiation, } \\
\text { immune response }\end{array}$ & $\begin{array}{l}\text { Breast cancer (76), prostate cancer (77), ovarian cancer } \\
\text { (78), multiple myeloma (79), neuroblastoma (11), } \\
\text { non-small cell lung cancer (80), pancreatic ductal } \\
\text { adenocarcinoma (81), endometrial cancer, renal cell } \\
\text { carcinoma (82), melanoma (83) }\end{array}$ \\
\hline
\end{tabular}


Additionally, HSPGs also influence cell-matrix interactions by binding matrix proteins such as fibronectin, laminin, thrombospondin, and collagen $(89,94)$. For example, SDC2 has been shown to be overexpressed in colon cancer cell lines and inhibition of SDC2 in these cells results in cell cycle arrest (69). Similarly, RKIP and HMGB2-dependent breast cancer survival and metastasis was shown to be regulated in SDC2 dependent manner (67). However, it is important to note that in addition to the pro-tumorigenic effects, some HSPGs, such as SDC2, exert tumor suppressive effects depending on the cancer type $(95,96)$.

Interestingly, HSPGs on the cell surface can also shed, generating soluble proteins that influence cellular proliferation by accumulating in intercellular spaces and sequestering growth factors (89). HSPGs are also often expressed in the tumor stroma and affect several cancer cell growth-enabling features (89). For example, stromal SDC1 that is released into the tumor microenvironment promotes breast carcinoma growth by enhancing FGF2 signaling (97). Interestingly, SDC1 shedding into the stroma is enhanced by heparanase expression, in part through removal and reduction of heparan sulfate chains (30). Thus, various components of the HS signaling pathway coordinate to promote carcinogenesis.

HSPGs secreted into the stroma can also inhibit cancer cell proliferation. For example, increased FGF2 signaling due to soluble HSPGs suppresses neuroblastoma proliferation $(11,98)$. Specifically, it has been shown that growing neuroblastoma cells with soluble HSPGs promote its differentiation by enhancing both basal and FGF1 mediated phosphorylation of ERK1/2 and expression of transcription factor ID1 (11). Another study has shown that the HSPG, type III TGF- $\beta$ receptor (TGFBR3) acts as a co-receptor in FGF2 mediated neuroblastome differentiation (98). Similarly, SDC1 that is expressed in multiple myeloma has been shown to activate WNT signaling by two mechanisms (99). First, Wnts bind to the SDC1 HS side chains and activates WNT pathway in a paracrine manner via Frizzled. Second, SDC1 binds to R-spondins produced in osteoblast and stabilizes Frizzled in a LGR4-dependent manner (99). In other instances, soluble HSPGs sequester growth factors, reducing certain proproliferative signals. For example, GPC3 promotes hepatocellular carcinoma growth by activating WNT signaling (100). However, contrary to this, soluble GPC3 has been shown to block hepatocellular carcinoma growth by blocking WNT signaling and MAP kinase and AKT pathways (101). Taken together, these studies underpin that HS and HSPGs can exert diverse cancer promoting or inhibitory functions depending upon the context.

\section{Apoptosis and Cellular Senescence Regulation}

HS and HSPGs can also play important role in the regulation of apoptosis and cellular senescence. For example, the upregulation of the RTK signaling pathway by HSPGs induces an antiapoptotic effect through upregulating phosphatidylinositol 3kinase (PI3K)- and Mitogen-Activated Protein Kinase (MAPK)mediated survival pathways (102). Additionally, HS and chondroitin sulfate directly inhibit $\mathrm{H}_{2} \mathrm{O}_{2}$-induced apoptosis by blocking cytochrome c release and caspase-3 and -9 activation (103). Death receptor-mediated apoptosis pathway, which is mediated through the cell surface receptors for Fas ligand (FasL) and Tumor Necrosis Factor-related Apoptosis-Inducing Ligand (TRAIL) can also be regulated by HSPGs. For example, SDC1 suppresses TRAIL-mediated apoptosis in multiple myeloma cells (104). The same study also reported that SDC1 knockdown in lymphoma cells protected them against FasL-mediated apoptosis. In addition to the regulation of apoptosis, a recent study also revealed that heparan sulfation is essential for preventing senescence (105). This study revealed that the depletion of 3'-phosphoadenosine $5^{\prime}$-phosphosulfate synthetase 2 (PAPSS2), an enzyme that synthesizes the sulfur donor PAPS, and the small molecule inhibitor-mediated repression of HS sulfation led to premature cell senescence (105). Collectively, these studies further demonstrate the importance of HS and HSPGs in the regulation of cancer growth relevant cellular processes, such as apoptosis and senescence.

\section{Cellular Differentiation Regulation}

HS, HSPGs, and HS modifiers have also been shown to determine the cellular differentiation state. In this regard, the role of HS modifiers in regulating epithelial-to-mesenchymal transition (EMT) is noteworthy. EMT plays an important role in metastatic progression and drug resistance (106). Cells overexpressing the HS modifier sulfatase 2 (SULF2) present with reduced levels of the trisulfated disaccharide UA(2S)-GlcNS(6S). This reduction is followed by an increase in EMT markers and WNT signaling (107). Tumor cell-mediated tumor stroma modulation can also suppress differentiation and increase proliferation. The expression of several HSPGs is low in neuroblasts and high in the Schwannian stroma, and neuroblastomas with a high T $\beta$ RIII, GPC1, and SDC3 expression have improved prognosis (11). The same study also found that soluble HSPGs and heparin promoted differentiation and decreased proliferation through FGFR1 and ERK phosphorylation. Similarly, another study has shown that neuroblastoma differentiation is promoted by release of a GPI-anchored HSPG, Glypican-6 (GPC6) through via Glycerophosphodiesterase (GDE2). This study also found that high GDE2 or low GPC6 level in neuroblastoma predicted significantly increased patient survival (108). These studies are of high significance as they make two major points; first, that the differentiation state of the cancer cells predict survival, and second, that HS and HSPGs are among the key regulators of cancer differentiation states.

\section{CELL-NON-AUTONOMOUS ROLES OF HS SIGNALING IN CANCER}

Several features of cancer such as sustained angiogenesis, tissue invasion and migration and immune evasion require a complex interplay between more than one cell type and involve multiple organ systems. In this section, we describe the cell-nonautonomous functions of HS and HSPGs in cancer initiation and progression. 


\section{Role in Angiogenesis}

Angiogenesis is considered a key requirement for cancer growth and progression (109). This is highlighted by the fact that several angiogenesis inhibitors are in clinical trials for cancer treatment (110). HS and HSPGs modify angiogenesis due to their effect on angiogenic factors, such as FGF, PDGF, and VEGF. For exmaple, SDC1 binds to VEGF, and SDC1 shedding increases the VEGF concentration in the matrix and promotes angiogenesis in myeloma (111). The same study also showed that heparanase expression increases SDC1 shedding (112). SDC1 is overexpressed in endothelial cells derived from patients with multiple myeloma. In addition to suppressing cell proliferation, RNAi silencing of SDC1 in patient-derived endothelial cells reduces capillary-like structure organization, which is correlated with reduced VEGF receptor (VEGFR)-2 surface expression (111). Other members of the syndecan family, such as SDC2 and SDC3, also affect tumor angiogenesis $(113,114)$.

Another HSPG with an opposing effect on angiogenesis is Perlecan. Perlecan is a secreted HSPG which is also found on cancer cell surface and in cancer microenvironment (115). Perlecan is shown to promotes angiogenesis in its intact form (115). However, Perlecan can also be partially cleaved by proteases, which results in a C-terminal fragment, called endorepellin, which has been shown to exert anti-angiogenic effects (116). Thus, HSPGs modulate tumor angiogenesis in multiple ways: they increase the tumor microenvironment VEGF concentration, affect VEGFR surface localization, and fine-tune interaction of VEGF with its receptor and coreceptor.

\section{Role in Immune Evasion}

Immune response is the first line of systemic defense against tumorigenesis (117). Recent success of immunotherapeutic approaches to treat cancer further highlights the importance of immune evasion mechanisms for cancer initiation and progression $(118,119)$. HSPGs can serve as cancer biomarkers, which can also be used to target antibodies for immunotherapies $(120,121)$. At the same time, evidence suggests that HSPGs in the extracellular matrix (ECM) or those expressed on bystander cells are involved in reducing immune signaling to dendritic cells (DCs) (122). One of the well-studied HSPGs roles in melanoma immunity involves myeloid-derived suppressor cells (MDSCs) that suppresses immunity against melanoma (122). Previous studies have shown that melanoma immune evasion involves myeloid-derived suppressor cells (MDSCs) that express an immune-suppressive molecule called dendritic cell-associated, HSPG-dependent integrin ligand (DC-HIL) (122). DL-HIL engages Syndecan-4 on effector T cell causing anergy (122). Furthermore, targeting DC-HIL with neutralizing antibody or its genetic knockout delayed the growth of transplantable B16 melanoma in syngeneic mice, which further strengthen the role of DC-HIL as a potential target for enhancing the immune response and cause tumor eradication (123).

HSPGs also affect innate immune response against cancer cells by modulating Natural Killer (NK) cell-mediated activity against cancer cells. NK cells exert their cytotoxic activity on cancer cells through recognition of specific ligands, one group of which is called the natural cytotoxicity receptors (NCR) (124). The NCRs bind to HSPGs and their interaction promotes NK cell-mediated cancer cell eradication (125). Additionally, it has been shown that cancer cells upregulate heparanase through activation of bromodomain PHD finger transcription factor (BPTF), leading to reduced NCR-HSPG interaction, which results in dampened NK cell response (126). Collectively, these studies demonstrate that by activating immune tolerance, enhancing signaling pathways, and interfering with immune celltumor interactions, HSPGs regulate immune evasion functions in cancer cells.

\section{Role in the Regulation of Extracellular Matrix Modification}

HSPGs, free HS chains and heparin are structural components of extracellular matrix (ECM) (12). The ECM is a major part of the tumor microenvironment and influences tumor progression by several mechanisms, including growth factor concentrations, angiogenesis, and immune infiltration (127). The changes in HSPGs and HS metabolizing enzymes vary widely with cancer type and have varying context dependent roles.

Right-sided colorectal cancers show that the expression of the HSPGs glypican-1,-3, and -6 and betaglycan are altered in non-metastatic tumors, whereas in metastatic tumors, only glypican-1 and SDC1 are modified. Interestingly, alterations were found in only non-metastatic tumors, affecting $\mathrm{N}$-sulfation, and the isoforms of heparan sulfate 6-O-sulfotransferase 1 (HS6ST1), heparan sulfate-glucosamine 3-sulfotransferase 3B1 (HS3ST3B1) and heparan sulfate-glucosamine 3sulfotransferase 5 (HS3ST5) (128). The HSPG SDC2 induces MMP-7-mediated E-cadherin shedding in colorectal cancer. E-Cadherin shedding led to reduced cell-to-cell contacts and the acquisition of a fibroblast-like morphology, which are both associated with cancer metastasis (129). Another important study showed that SDC1-positive human mammary fibroblasts (HMF) induced extracellular matrix remodeling by promoting an aligned fiber architecture, which promoted directional migration and invasion of breast cancer cells (130).

Apart from syndecans, perlecan and agrin, two other basement membrane constituents are also involved in cancer progression (131-133). Antisense RNA against perlecan inhibits tumor growth and angiogenesis in colon carcinoma (134). Moreover, the ECM protein agrin stimulated osteosarcoma cell growth and migration. Agrin also induces a switch from topoisomerase I to topoisomerase II (135). Therefore, these studies collectively reveal the role of HSPG ECM constituents and cell surface HSPGs in regulating cell-to-cell and cell-matrix adhesion, which in turn control tumor cell migration and shedding.

\section{TARGETING HS AND HSPGs FOR CANCER TREATMENT}

Understanding the biology behind HS and HSPG deregulation in cancers has enabled the development of 
various therapeutic strategies aimed at various HS- and HSPG-mediated cancer growth and progression enabling features. Small molecule inhibitors, which interfere with the activities of various enzymes involved in HSPG synthesis and modification, have been developed (6). Additionally, small molecule inhibitors and monoclonal antibodies, which target interactions between HSPGs and their targets, are being developed $(136,137)$. Below, we describe some of these agents and their value as anti-cancer agents.

\section{Antibody and Small Molecule Targeting HS-Modifying Enzymes, HS, and HSPGs}

Among the enzymes involved in HS synthesis and modifications, heparanases, and sulfatases are considered good drug targets. Heparanase is overexpressed in a wide-variety of solid tumors and hematological malignancies (29). A previous study assessed the therapeutic value of heparanase targeting using heparanse-neutralizing antibodies for the treatment of diffuse non-Hodgkin's B-cell lymphoma and follicular lymphoma (138). This study found that heparanase inhibition blocked xenograft tumors and growth of lymphoma cells in the bones of mice (138). Additional studies have shown that antibody-mediated anti-heparanase-therapies inhibit cell invasion and tumor metastasis (138-140). Recently, a small molecule inhibitor of hepranase was developed and was shown to reduce metastatic attributes in a model of hepatocellular carcinoma (141). Thus, these studies collectively establish heparanase as a potential drug target for cancer therapy.

Small molecule inhibitors, which prevent growth hormone binding to HSPG, reduce the proliferative HSPG-mediated signal. A similarity-based screening of small molecule libraries identified bi-naphthalenic compounds, which can inhibit FGF binding to both, HSPGs and FGFR1 binding. In vitro and ex vivo, these compounds inhibit FGF2 activity in angiogenesis models, with improved therapeutic potency (142). Monoclonal antibodies developed against the HS chain on GPC3 inhibit $\mathrm{Wnt} 3 \mathrm{a} / \beta$-catenin activation, recapitulating GPC3 knockdown by reducing HCC migration and motility (137).

Small molecule inhibitors against sulfatases have shown promise in inhibiting tumor growth. A disulfonyl derivative of phenyl-tert-butyl nitrone (PBN) called OKN-007 inhibited Sulf2 activity in hepatocellular carcinoma (HCC) cell lines and blocked HCC tumor xenograft growth in mice (136).

HS signaling modulation also affects immune cell trafficking and associated immune responses. Deletion of the glycosyltransferase gene exostosin glycosyltransferase 1 (Ext1), which is essential for HS chain formation, in myxovirus resistance-1 (Mx-1)-expressing bone marrow stromal cells increased hematopoietic stem cells (HSCs) efflux from the bone marrow to the spleen in response to granulocyte colony-stimulating factor. Thus, a therapeutic that targets Extl may help mobilize immune cells to target cancer cells (143). For detailed review on the role of different enzymes in HS synthesis and modification readers are referred to a review by Bishop et al. (12).

\section{Heparan Sulfate Mimetics}

HS mimetics were also used as anti-cancer agents. HS mimetics induce an immune response against lymphoma through activation of natural killer (NK) cells (144). The HS mimetic PG545, in addition to its anti-heparanase and anti-angiogenic effect shows pleiotropic effect by enhancing toll-like receptor 9 (TLR9) activation through increasing the TLR9 ligand CpG in DCs. It was shown that treatment with PG545 resulted in the accumulation of CpG in the lysosomal compartment of DCs. This in turn enhanced the IL-12 production, which was essential for the ability of PG545 to activate NK cells (144). Furthermore, PG545 was also shown to directly bind to WNT3A and WNT7A and inhibits $W N T / \beta$-catenin signaling, inhibiting proliferation in pancreatic tumor cell lines (145). These studies further highlight the possibility of using heparin sulfate mimetics as agents for cancer therapy.

\section{HSPGs as Immunotherapeutic Targets}

Some recent studies have also indicated that the upregulation of HSPGs on cancer cells can be used as unique biomarkers that can be targeted to selectively deliver cytotoxic drugs (146, 147). A recent study that analyzed differential expression of cell surface proteins on neuroblastoma identified the HSPG, Glypican-2 (GPC2) as selectively expressed on neuroblastoma where it enhances neuroblastoma proliferation (148). The researchers were able to develop an antibody drug conjugate that selectively eradicated GPC2 positive neuroblastoma (148). This is another exciting area of emerging research where HSPGs can be exploited to serve as targets for selective drug delivery to cancer cells.

\section{CONCLUSION}

Recent cancer therapies have largely focused on targeting driver mutations and their downstream effectors. However, the emerging body of evidence now shows that driver-mutations are, in fact, enhanced and modified by a host of other modifications as cancer evolves. HS and HSPG deregulation are major contributing factors to cancer evolution. This review has covered some of the well-established and emerging roles of HS and HSPGs in cancer. However, new, non-canonical functions of HSPGs are still being discovered. For instance, in addition to modulating growth factors and RTK interactions, HSPGs also transport growth factors directly to the nucleus, where these factors modify gene regulation (149). HSPGs have also been shown to influence cancer exosome shedding and uptake, thereby modulating cell-to-cell communication between cancer and healthy fibroblasts, immune cells, and endothelial cells (150, 151). HSPGs can also influence actin cytoskeleton remodeling and cancer cell motility (95). The HSPG, SDC2 binds Ezrin, a cytoskeletal protein (152) and serves as adapter molecules for IGF1 mediated activation of ERK (95). Additionally, HSPGs are implicated in lipoprotein uptake and cellular stress signaling $(153,154)$. As more researchers validate these findings, newer 
areas of HS- and HSPG-mediated regulation will be discovered. Additionally, as cancer treatment moves from single target to combination therapies, HS- and HSPG-targeting therapies will likely emerge as a major new direction for cancer therapeutics.

\section{AUTHOR CONTRIBUTIONS}

All authors listed have made a substantial, direct and intellectual contribution to the work, and approved it for publication.

\section{REFERENCES}

1. Hanahan D, Weinberg RA. Hallmarks of cancer: the next generation. Cell (2011) 144:646-74. doi: 10.1016/j.cell.2011.02.013

2. Prydz K, Dalen KT. Synthesis and sorting of proteoglycans. J Cell Sci. (2000) 113 (Pt 2):193-205.

3. Lamanna WC, Kalus I, Padva M, Baldwin RJ, Merry CL, Dierks T. The heparanome-the enigma of encoding and decoding heparan sulfate sulfation. $J$ Biotechnol. (2007) 129:290-307. doi: 10.1016/j.jbiotec.2007.01.022

4. Zhang L, David G, Esko JD. Repetitive ser-gly sequences enhance heparan sulfate assembly in proteoglycans. J Biol Chem. (1995) 270:27127-35. doi: $10.1074 / \mathrm{jbc} .270 .45 .27127$

5. Selva EM, Perrimon N. Role of heparan sulfate proteoglycans in cell signaling and cancer. Adv Cancer Res. (2001) 83:67-80. doi: 10.1016/S0065-230X83003-7

6. Hammond E, Khurana A, Shridhar V, Dredge K. The role of heparanase and sulfatases in the modification of Heparan sulfate proteoglycans within the tumor microenvironment and opportunities for novel cancer therapeutics. Front Oncol. (2014) 4:195. doi: 10.3389/fonc.2014.00195

7. Alexander CM, Reichsman F, Hinkes MT, Lincecum J, Becker KA, Cumberledge S, et al. Syndecan-1 is required for Wnt-1-induced mammary tumorigenesis in mice. Nat Genet. (2000) 25:329-32. doi: 10.1038/77108

8. Dhodapkar MV, Abe E, Theus A, Lacy M, Langford JK, Barlogie B, et al. Syndecan-1 is a multifunctional regulator of myeloma pathobiology: control of tumor cell survival, growth, and bone cell differentiation. Blood (1998) 91:2679-88.

9. Kleeff J, Ishiwata T, Kumbasar A, Friess H, Buchler MW, Lander AD, et al. The cell-surface heparan sulfate proteoglycan glypican-1 regulates growth factor action in pancreatic carcinoma cells and is overexpressed in human pancreatic cancer. J Clin Invest. (1998) 102:1662-73. doi: 10.1172/JCI4105

10. Williamson D, Selfe J, Gordon T, Lu YJ, Pritchard-Jones K, Murai K, et al. Role for amplification and expression of glypican-5 in rhabdomyosarcoma. Cancer Res. (2007) 67:57-65. doi: 10.1158/0008-5472.CAN-06-1650

11. Knelson EH, Gaviglio AL, Nee JC, Starr MD, Nixon AB, Marcus SG, et al. Stromal heparan sulfate differentiates neuroblasts to suppress neuroblastoma growth. J Clin Invest. (2014) 124:3016-31. doi: 10.1172/JCI74270

12. Bishop JR, Schuksz M, Esko JD. Heparan sulphate proteoglycans fine-tune mammalian physiology. Nature (2007) 446:1030-7. doi: 10.1038/nature05817

13. Ferguson BW, Datta S. Role of heparan sulfate 2-o-sulfotransferase in prostate cancer cell proliferation, invasion, and growth factor signaling. Prostate Cancer (2011) 2011:893208. doi: 10.1155/2011/893208

14. Hwang JA, Kim Y, Hong SH, Lee J, Cho YG, Han JY, et al. Epigenetic inactivation of heparan sulfate (glucosamine) 3-O-sulfotransferase 2 in lung cancer and its role in tumorigenesis. PLoS ONE (2013) 8:e79634. doi: 10.1371/journal.pone.0079634

15. Vijaya Kumar A, Salem Gassar E, Spillmann D, Stock C, Sen YP, Zhang T, et al. HS3ST2 modulates breast cancer cell invasiveness via MAP kinase- and Tcf4 (Tcf712)-dependent regulation of protease and cadherin expression. Int J Cancer (2014) 135:2579-92. doi: 10.1002/ijc.28921

\section{ACKNOWLEDGMENTS}

We gratefully acknowledge grants from the National Institutes of Health: R01CA195077-01A1 (NW) and R01CA200919-01 (NW) and R01CA218008-01A1 and R21CA197758 (NW). NW is also supported by a Research Scholar Grant from the American Cancer Society (128347-RSG-15-212-01-TBG). Grant support from Elsa $U$ Pardee Foundation, research support from Yale SPORE in Lung Cancer (3P50CA196530) and an administrative supplement from NIH (3P50CA196530-02S1) are also acknowledged.

16. Zhang L, Song K, Zhou L, Xie Z, Zhou P, Zhao Y, et al. Heparan sulfate Dglucosaminyl 3-O-sulfotransferase-3B1 (HS3ST3B1) promotes angiogenesis and proliferation by induction of VEGF in acute myeloid leukemia cells. $J$ Cell Biochem. (2015) 116:1101-12. doi: 10.1002/jcb.25066

17. Biroccio A, Cherfils-Vicini J, Augereau A, Pinte S, Bauwens S, Ye J, et al. TRF2 inhibits a cell-extrinsic pathway through which natural killer cells eliminate cancer cells. Nat Cell Biol. (2013) 15:818-28. doi: 10.1038/nc b2774

18. Song K, Li Q, Jiang ZZ, Guo CW, Li P. Heparan sulfate D-glucosaminyl 3-O-sulfotransferase-3B1, a novel epithelial-mesenchymal transition inducer in pancreatic cancer. Cancer Biol Ther. (2011) 12:388-98. doi: 10.4161/cbt.12.5.15957

19. Cole CL, Rushton G, Jayson GC, Avizienyte E. Ovarian cancer cell heparan sulfate 6-O-sulfotransferases regulate an angiogenic program induced by heparin-binding epidermal growth factor (EGF)-like growth factor/EGF receptor signaling. J Biol Chem. (2014) 289:10488-501. doi: 10.1074/jbc.M113.534263

20. Hatabe $S$, Kimura $H$, Arao $T$, Kato $H$, Hayashi $H$, Nagai $T$, et al. Overexpression of heparan sulfate 6-O-sulfotransferase-2 in colorectal cancer. Mol Clin Oncol. (2013) 1:845-50. doi: 10.3892/mco.2013.151

21. Pollari S, Kakonen RS, Mohammad KS, Rissanen JP, Halleen JM, Warri A, et al. Heparin-like polysaccharides reduce osteolytic bone destruction and tumor growth in a mouse model of breast cancer bone metastasis. Mol Cancer Res. (2012) 10:597-604. doi: 10.1158/1541-7786.MCR-11-0482

22. Qu H, Zheng L, Pu J, Mei H, Xiang X, Zhao X, et al. miRNA-558 promotes tumorigenesis and aggressiveness of neuroblastoma cells through activating the transcription of heparanase. Hum Mol Genet. (2015) 24:2539-51. doi: $10.1093 / \mathrm{hmg} / \mathrm{ddv} 018$

23. Theodoro TR, de Matos LL, Sant Anna AV, Fonseca FL, Semedo P, Martins LC, et al. Heparanase expression in circulating lymphocytes of breast cancer patients depends on the presence of the primary tumor and/or systemic metastasis. Neoplasia (2007) 9:504-10. doi: 10.1593/neo.07241

24. Lerner I, Baraz L, Pikarsky E, Meirovitz A, Edovitsky E, Peretz T, et al. Function of heparanase in prostate tumorigenesis: potential for therapy. Clin Cancer Res. (2008) 14:668-76. doi: 10.1158/1078-0432.CCR-07-1866

25. Friedmann Y, Vlodavsky I, Aingorn H, Aviv A, Peretz T, Pecker I, et al. Expression of heparanase in normal, dysplastic, and neoplastic human colonic mucosa and stroma. Evidence for its role in colonic tumorigenesis. Am J Pathol. (2000) 157:1167-75. doi: 10.1016/S0002-9440(10)64632-9

26. Cohen E, Doweck I, Naroditsky I, Ben-Izhak O, Kremer R, Best LA, et al. Heparanase is overexpressed in lung cancer and correlates inversely with patient survival. Cancer (2008) 113:1004-11. doi: 10.1002/cncr.23680

27. Chen X, Jiang W, Yue C, Zhang W, Tong C, Dai D, et al. Heparanase contributes to trans-endothelial migration of hepatocellular carcinoma cells. J Cancer (2017) 8:3309-17. doi: 10.7150/jca.20159

28. Zheng H, Ruan J, Zhao P, Chen S, Pan L, Liu J. Heparanase is involved in proliferation and invasion of ovarian cancer cells. Cancer Biomark (2015) 15:525-34. doi: 10.3233/CBM-150459

29. Koliopanos A, Friess H, Kleeff J, Shi X, Liao Q, Pecker I, et al. Heparanase expression in primary and metastatic pancreatic cancer. Cancer Res. (2001) 61:4655-9. 
30. Yang Y, Macleod V, Miao HQ, Theus A, Zhan F, Shaughnessy JD Jr, et al. Heparanase enhances syndecan-1 shedding: a novel mechanism for stimulation of tumor growth and metastasis. J Biol Chem. (2007) 282:13326-33. doi: 10.1074/jbc.M611259200

31. Tatrai P, Egedi K, Somoracz A, van Kuppevelt TH, Ten Dam G, Lyon M, et al. Quantitative and qualitative alterations of heparan sulfate in fibrogenic liver diseases and hepatocellular cancer. J Histochem Cytochem. (2010) 58:429-41. doi: 10.1369/jhc.2010.955161

32. Lai JP, Sandhu DS, Shire AM, Roberts LR. The tumor suppressor function of human sulfatase 1 (SULF1) in carcinogenesis. J Gastrointest Cancer (2008) 39:149-58. doi: 10.1007/s12029-009-9058-y

33. Lai JP, Sandhu DS, Yu C, Han T, Moser CD, Jackson KK, et al. Sulfatase 2 up-regulates glypican 3, promotes fibroblast growth factor signaling, and decreases survival in hepatocellular carcinoma. Hepatology (2008) 47:121122. doi: 10.1002/hep. 22202

34. Phillips JJ, Huillard E, Robinson AE, Ward A, Lum DH, Polley MY, et al. Heparan sulfate sulfatase SULF2 regulates PDGFRalpha signaling and growth in human and mouse malignant glioma. J Clin Invest. (2012) 122:911-22. doi: 10.1172/JCI58215

35. Lai JP, Oseini AM, Moser CD, Yu C, Elsawa SF, Hu C, et al. The oncogenic effect of sulfatase 2 in human hepatocellular carcinoma is mediated in part by glypican 3-dependent Wnt activation. Hepatology (2010) 52:1680-9. doi: 10.1002/hep. 23848

36. Lai JP, Sandhu DS, Yu C, Moser CD, Hu C, Shire AM, et al. Sulfatase 2 protects hepatocellular carcinoma cells against apoptosis induced by the PI3K inhibitor LY294002 and ERK and JNK kinase inhibitors. Liver Int. (2010) 30:1522-8. doi: 10.1111/j.1478-3231.2010.02336.x

37. Batmunkh E, Tatrai P, Szabo E, Lodi C, Holczbauer A, Paska C, et al. Comparison of the expression of agrin, a basement membrane heparan sulfate proteoglycan, in cholangiocarcinoma and hepatocellular carcinoma. Hum Pathol. (2007) 38:1508-15. doi: 10.1016/j.humpath.2007.02.017

38. Tatrai P, Dudas J, Batmunkh E, Mathe M, Zalatnai A, Schaff Z, et al. Agrin, a novel basement membrane component in human and rat liver, accumulates in cirrhosis and hepatocellular carcinoma. Lab Invest. (2006) 86:1149-60. doi: 10.1038/labinvest.3700475

39. Warth A, Kroger S, Wolburg H. Redistribution of aquaporin-4 in human glioblastoma correlates with loss of agrin immunoreactivity from brain capillary basal laminae. Acta Neuropathol. (2004) 107:311-8. doi: 10.1007/s00401-003-0812-0

40. McFarlane S, Coulter JA, Tibbits P, O'Grady A, McFarlane C, Montgomery $\mathrm{N}$, et al. CD44 increases the efficiency of distant metastasis of breast cancer. Oncotarget (2015) 6:11465-76. doi: 10.18632/oncotarget.3410

41. Huh JW, Kim HR, Kim YJ, Lee JH, Park YS, Cho SH, et al. Expression of standard CD44 in human colorectal carcinoma: association with prognosis. Pathol Int. (2009) 59:241-6. doi: 10.1111/j.1440-1827.2009.02357.x

42. Lyons AJ, Jones J. Cell adhesion molecules, the extracellular matrix and oral squamous carcinoma. Int J Oral Maxillofac Surg. (2007) 36:671-9. doi: 10.1016/j.ijom.2007.04.002

43. Dietrich A, Tanczos E, Vanscheidt W, Schopf E, Simon JC. High CD44 surface expression on primary tumours of malignant melanoma correlates with increased metastatic risk and reduced survival. Eur J Cancer (1997) 33:926-30. doi: 10.1016/S0959-8049(96)00512-6

44. Munchar MJ, Sharifah NA, Jamal R, Looi LM. CD44s expression correlated with the International Neuroblastoma Pathology Classification (Shimada system) for neuroblastic tumours. Pathology (2003) 35:125-9. doi: 10.1097/01268031-200335020-00005

45. Iozzo RV, Zoeller JJ, Nystrom A. Basement membrane proteoglycans: modulators par excellence of cancer growth and angiogenesis. Mol Cells (2009) 27:503-13. doi: 10.1007/s10059-009-0069-0

46. O’Reilly MS, Boehm T, Shing Y, Fukai N, Vasios G, Lane WS, et al. Endostatin: an endogenous inhibitor of angiogenesis and tumor growth. Cell (1997) 88:277-85. doi: 10.1016/S0092-8674(00)81848-6

47. Huang G, Ge G, Izzi V, Greenspan DS. alpha3 Chains of type V collagen regulate breast tumour growth via glypican-1. Nat Commun. (2017) 8:14351. doi: $10.1038 /$ ncomms 14351

48. Tanaka M, Ishikawa S, Ushiku T, Morikawa T, Isagawa T, Yamagishi M, et al. EVI1 modulates oncogenic role of GPC1 in pancreatic carcinogenesis. Oncotarget (2017) 8:99552-66. doi: 10.18632/oncotarget.20601
49. Su G, Meyer K, Nandini CD, Qiao D, Salamat S, Friedl A. Glypican1 is frequently overexpressed in human gliomas and enhances FGF-2 signaling in glioma cells. Am J Pathol. (2006) 168:2014-26. doi: 10.2353/ajpath.2006.050800

50. Feng M, Gao W, Wang R, Chen W, Man YG, Figg WD, et al. Therapeutically targeting glypican-3 via a conformation-specific single-domain antibody in hepatocellular carcinoma. Proc Natl Acad Sci USA. (2013) 110:E1083-91. doi: 10.1073/pnas.1217868110

51. Yamanaka K, Ito Y, Okuyama N, Noda K, Matsumoto H, Yoshida H, et al. Immunohistochemical study of glypican 3 in thyroid cancer. Oncology (2007) 73:389-94. doi: 10.1159/000136159

52. Boily G, Ouellet S, Langlois S, Lariviere M, Drouin R, Sinnett D. In vivo footprinting analysis of the Glypican 3 (GPC3) promoter region in neuroblastoma cells. Biochim Biophys Acta (2007) 1769:182-93. doi: 10.1016/j.bbaexp.2007.01.014

53. Toretsky JA, Zitomersky NL, Eskenazi AE, Voigt RW, Strauch ED, Sun CC, et al. Glypican-3 expression in Wilms tumor and hepatoblastoma. J Pediatr Hematol Oncol. (2001) 23:496-9. doi: 10.1097/00043426-200111000-00006

54. Esheba GE, Pate LL, Longacre TA. Oncofetal protein glypican-3 distinguishes yolk sac tumor from clear cell carcinoma of the ovary. Am J Surg Pathol. (2008) 32:600-7. doi: 10.1097/PAS.0b013e31815a565a

55. Lin Q, Xiong LW, Pan XF, Gen JF, Bao GL, Sha HF, et al. Expression of GPC3 protein and its significance in lung squamous cell carcinoma. Med Oncol. (2012) 29:663-9. doi: 10.1007/s12032-011-9973-1

56. Midorikawa $\mathrm{Y}$, Ishikawa $\mathrm{S}$, Iwanari $\mathrm{H}$, Imamura $\mathrm{T}$, Sakamoto $\mathrm{H}$, Miyazono K, et al. Glypican-3, overexpressed in hepatocellular carcinoma, modulates FGF2 and BMP-7 signaling. Int J Cancer (2003) 103:455-65. doi: 10.1002/ijc. 10856

57. Li Y, Miao L, Cai H, Ding J, Xiao Y, Yang J, et al. The overexpression of glypican-5 promotes cancer cell migration and is associated with shorter overall survival in non-small cell lung cancer. Oncol Lett. (2013) 6:1565-72. doi: 10.3892/ol.2013.1622

58. Li Y, Sheu CC, Ye Y, de Andrade M, Wang L, Chang SC, et al. Genetic variants and risk of lung cancer in never smokers: a genome-wide association study. Lancet Oncol. (2010) 11:321-30. doi: 10.1016/S1470-2045(10) 70042-5

59. Datta S, Pierce M, Datta MW. Perlecan signaling: helping hedgehog stimulate prostate cancer growth. Int J Biochem Cell Biol. (2006) 38:1855-61. doi: 10.1016/j.biocel.2006.03.022

60. Kadenhe-Chiweshe A, Papa J, McCrudden KW, Frischer J, Bae JO, Huang J, et al. Sustained VEGF blockade results in microenvironmental sequestration of VEGF by tumors and persistent VEGF receptor-2 activation. Mol Cancer Res. (2008) 6:1-9. doi: 10.1158/1541-7786.MCR-07-0101

61. Gronborg M, Kristiansen TZ, Iwahori A, Chang R, Reddy R, Sato N, et al. Biomarker discovery from pancreatic cancer secretome using a differential proteomic approach. Mol Cell Proteomics (2006) 5:157-71. doi: 10.1074/mcp.M500178-MCP200

62. Cohen IR, Murdoch AD, Naso MF, Marchetti D, Berd D, Iozzo RV. Abnormal expression of perlecan proteoglycan in metastatic melanomas. Cancer Res. (1994) 54:5771-4.

63. Malek-Hosseini Z, Jelodar S, Talei A, Ghaderi A, Doroudchi M. Elevated Syndecan-1 levels in the sera of patients with breast cancer correlate with tumor size. Breast Cancer (2017) 24:742-7. doi: 10.1007/s12282-0170773-0

64. Conejo JR, Kleeff J, Koliopanos A, Matsuda K, Zhu ZW, Goecke $\mathrm{H}$, et al. Syndecan-1 expression is up-regulated in pancreatic but not in other gastrointestinal cancers. Int $J$ Cancer (2000) 88:12-20. doi: 10.1002/1097-0215(20001001)88:1<12::AID-IJC3>3.0.CO;2-T

65. Davies EJ, Blackhall FH, Shanks JH, David G, McGown AT, Swindell $\mathrm{R}$, et al. Distribution and clinical significance of heparan sulfate proteoglycans in ovarian cancer. Clin Cancer Res. (2004) 10:5178-86. doi: 10.1158/1078-0432.CCR-03-0103

66. Khotskaya YB, Dai Y, Ritchie JP, MacLeod V, Yang Y, Zinn K, et al. Syndecan-1 is required for robust growth, vascularization, and metastasis of myeloma tumors in vivo. J Biol Chem. (2009) 284:26085-95. doi: 10.1074/jbc.M109.018473

67. Sun M, Gomes S, Chen P, Frankenberger CA, Sankarasharma D, Chung $\mathrm{CH}$, et al. RKIP and HMGA2 regulate breast tumor survival and metastasis 
through lysyl oxidase and syndecan-2. Oncogene (2014) 33:3528-37. doi: $10.1038 /$ onc.2013.328

68. Popovic A, Demirovic A, Spajic B, Stimac G, Kruslin B, Tomas D. Expression and prognostic role of syndecan-2 in prostate cancer. Prostate Cancer Prostatic Dis. (2010) 13:78-82. doi: 10.1038/pcan.2009.43

69. Park H, Kim Y, Lim Y, Han I, Oh ES. Syndecan-2 mediates adhesion and proliferation of colon carcinoma cells. J Biol Chem. (2002) 277:29730-6. doi: $10.1074 /$ jbc.M202435200

70. Marzioni D, Lorenzi T, Mazzucchelli R, Capparuccia L, Morroni M, Fiorini R, et al. Expression of basic fibroblast growth factor, its receptors and syndecans in bladder cancer. Int J Immunopathol Pharmacol. (2009) 22:627-38. doi: 10.1177/039463200902200308

71. Fears CY, Gladson CL, Woods A. Syndecan-2 is expressed in the microvasculature of gliomas and regulates angiogenic processes in microvascular endothelial cells. J Biol Chem. (2006) 281:14533-6. doi: 10.1074/jbc.C600075200

72. Park H, Han I, Kwon HJ, Oh ES. Focal adhesion kinase regulates syndecan2-mediated tumorigenic activity of HT1080 fibrosarcoma cells. Cancer Res. (2005) 65:9899-905. doi: 10.1158/0008-5472.CAN-05-1386

73. Yao J, Li WY, Li SG, Feng XS, Gao SG. Midkine promotes perineural invasion in human pancreatic cancer. World J Gastroenterol. (2014) 20:3018-24. doi: 10.3748/wjg.v20.i11.3018

74. Gatza CE, Holtzhausen A, Kirkbride KC, Morton A, Gatza ML, Datto $\mathrm{MB}$, et al. Type III TGF-beta receptor enhances colon cancer cell migration and anchorage-independent growth. Neoplasia (2011) 13:758-70. doi: $10.1593 /$ neo. 11528

75. Bernabeu C, Lopez-Novoa JM, Quintanilla M. The emerging role of TGF-beta superfamily coreceptors in cancer. Biochim Biophys Acta (2009) 1792:954-73. doi: 10.1016/j.bbadis.2009.07.003

76. Dong M, How T, Kirkbride KC, Gordon KJ, Lee JD, Hempel N, et al. The type III TGF-beta receptor suppresses breast cancer progression. J Clin Invest. (2007) 117:206-17. doi: 10.1172/JCI29293

77. Turley RS, Finger EC, Hempel N, How T, Fields TA, Blobe GC. The type III transforming growth factor-beta receptor as a novel tumor suppressor gene in prostate cancer. Cancer Res. (2007) 67:1090-8. doi: 10.1158/0008-5472.CAN-06-3117

78. Hempel N, How T, Dong M, Murphy SK, Fields TA, Blobe GC. Loss of betaglycan expression in ovarian cancer: role in motility and invasion. Cancer Res. (2007) 67:5231-8. doi: 10.1158/0008-5472.CAN-07-0035

79. Lambert KE, Huang H, Mythreye K, Blobe GC. The type III transforming growth factor-beta receptor inhibits proliferation, migration, and adhesion in human myeloma cells. Mol Biol Cell. (2011) 22:1463-72. doi: 10.1091/mbc.e10-11-0877

80. Finger EC, Turley RS, Dong M, How T, Fields TA, Blobe GC. TbetaRIII suppresses non-small cell lung cancer invasiveness and tumorigenicity. Carcinogenesis (2008) 29:528-35. doi: 10.1093/carcin/bgm289

81. Gordon KJ, Dong M, Chislock EM, Fields TA, Blobe GC. Loss of type III transforming growth factor beta receptor expression increases motility and invasiveness associated with epithelial to mesenchymal transition during pancreatic cancer progression. Carcinogenesis (2008) 29:252-62. doi: 10.1093/carcin/bgm249

82. Copland JA, Luxon BA, Ajani L, Maity T, Campagnaro E, Guo H, et al. Genomic profiling identifies alterations in TGFbeta signaling through loss of TGFbeta receptor expression in human renal cell carcinogenesis and progression. Oncogene (2003) 22:8053-62. doi: 10.1038/sj.onc.1206835

83. Hanks BA, Holtzhausen A, Evans KS, Jamieson R, Gimpel P, Campbell $\mathrm{OM}$, et al. Type III TGF-beta receptor downregulation generates an immunotolerant tumor microenvironment. J Clin Invest. (2013) 123:3925-40. doi: 10.1172/JCI65745

84. Raman K, Kuberan B. Chemical tumor biology of heparan sulfate proteoglycans. Curr Chem Biol. (2010) 4:20-31. doi: $10.2174 / 187231310790226206$

85. Higashiyama S, Abraham JA, Klagsbrun M. Heparin-binding EGF-like growth factor stimulation of smooth muscle cell migration: dependence on interactions with cell surface heparan sulfate. J Cell Biol. (1993) 122:933-40. doi: $10.1083 /$ jcb.122.4.933

86. Matsuda K, Maruyama H, Guo F, Kleeff J, Itakura J, Matsumoto Y, et al. Glypican-1 is overexpressed in human breast cancer and modulates the mitogenic effects of multiple heparin-binding growth factors in breast cancer cells. Cancer Res. (2001) 61:5562-9.

87. Lindblom P, Gerhardt H, Liebner S, Abramsson A, Enge M, Hellstrom $\mathrm{M}$, et al. Endothelial PDGF-B retention is required for proper investment of pericytes in the microvessel wall. Genes Dev. (2003) 17:1835-40. doi: $10.1101 /$ gad.266803

88. Paine-Saunders S, Viviano BL, Economides AN, Saunders S. Heparan sulfate proteoglycans retain Noggin at the cell surface: a potential mechanism for shaping bone morphogenetic protein gradients. J Biol Chem. (2002) 277:2089-96. doi: 10.1074/jbc.M109151200

89. Whitelock JM, Iozzo RV. Heparan sulfate: a complex polymer charged with biological activity. Chem Rev. (2005) 105:2745-64. doi: 10.1021/cr0 $10213 \mathrm{~m}$

90. Turner N, Grose R. Fibroblast growth factor signalling: from development to cancer. Nat Rev Cancer. (2010) 10:116-29. doi: 10.1038/nrc2780

91. Spivak-Kroizman T, Lemmon MA, Dikic I, Ladbury JE, Pinchasi D, Huang J, et al. Heparin-induced oligomerization of FGF molecules is responsible for FGF receptor dimerization, activation, and cell proliferation. Cell (1994) 79:1015-24. doi: 10.1016/0092-8674(94)90032-9

92. Iozzo RV, Sanderson RD. Proteoglycans in cancer biology, tumour microenvironment and angiogenesis. J Cell Mol Med. (2011) 15:1013-31. doi: 10.1111/j.1582-4934.2010.01236.x

93. Aikawa T, Whipple CA, Lopez ME, Gunn J, Young A, Lander AD, et al. Glypican-1 modulates the angiogenic and metastatic potential of human and mouse cancer cells. J Clin Invest. (2008) 118:89-99. doi: 10.1172/JCI32412

94. Carey DJ, Crumbling DM, Stahl RC, Evans DM. Association of cell surface heparan sulfate proteoglycans of Schwann cells with extracellular matrix proteins. J Biol Chem. (1990) 265:20627-33.

95. Mytilinaiou M, Nikitovic D, Berdiaki A, Kostouras A, Papoutsidakis A, Tsatsakis AM, et al. Emerging roles of syndecan 2 in epithelial and mesenchymal cancer progression. IUBMB Life. (2017) 69:824-33. doi: $10.1002 /$ iub. 1678

96. Afratis NA, Nikitovic D, Multhaupt HA, Theocharis AD, Couchman JR, Karamanos NK. Syndecans - key regulators of cell signaling and biological functions. FEBS J. (2017) 284:27-41. doi: 10.1111/febs.13940

97. Maeda T, Desouky J, Friedl A. Syndecan-1 expression by stromal fibroblasts promotes breast carcinoma growth in vivo and stimulates tumor angiogenesis. Oncogene (2006) 25:1408-12. doi: 10.1038/sj.onc.1209168

98. Knelson EH, Gaviglio AL, Tewari AK, Armstrong MB, Mythreye K, Blobe GC. Type III TGF-beta receptor promotes FGF2-mediated neuronal differentiation in neuroblastoma. J Clin Invest. (2013) 123:4786-98. doi: 10.1172/JCI69657

99. Ren Z, van Andel H, de Lau W, Hartholt RB, Maurice MM, Clevers $\mathrm{H}$, et al. Syndecan-1 promotes Wnt/beta-catenin signaling in multiple myeloma by presenting Wnts and R-spondins. Blood (2017) 131:982-94. doi: 10.1182/blood-2017-07-797050

100. Gao W, Ho M. The role of glypican-3 in regulating Wnt in hepatocellular carcinomas. Cancer Rep. (2011) 1:14-9.

101. Zittermann SI, Capurro MI, Shi W, Filmus J. Soluble glypican 3 inhibits the growth of hepatocellular carcinoma in vitro and in vivo. Int J Cancer (2010) 126:1291-301. doi: 10.1002/ijc.24941

102. Lemmon MA, Schlessinger J. Cell signaling by receptor tyrosine kinases. Cell (2010) 141:1117-34. doi: 10.1016/j.cell.2010.06.011

103. Yue XL, Lehri S, Li P, Barbier-Chassefiere V, Petit E, Huang QF, et al. Insights on a new path of pre-mitochondrial apoptosis regulation by a glycosaminoglycan mimetic. Cell Death Diff. (2009) 16:770-81. doi: $10.1038 /$ cdd. 2009.9

104. Wu YH, Yang CY, Chien WL, Lin KI, Lai MZ. Removal of syndecan-1 promotes TRAIL-induced apoptosis in myeloma cells. J Immunol. (2012) 188:2914-21. doi: 10.4049/jimmunol.1102065

105. Jung SH, Lee HC, Yu DM, Kim BC, Park SM, Lee YS, et al. Heparan sulfation is essential for the prevention of cellular senescence. Cell Death Differ. (2016) 23:417-29. doi: 10.1038/cdd.2015.107

106. Thiery JP. Epithelial-mesenchymal transitions in tumour progression. Nat Rev Cancer (2002) 2:442-54. doi: 10.1038/nrc822

107. Vicente CM, Lima MA, Nader HB, Toma L. SULF2 overexpression positively regulates tumorigenicity of human prostate cancer cells. J Exp Clin Cancer Res. (2015) 34:25. doi: 10.1186/s13046-015-0141-x 
108. Matas-Rico E, van Veen M, Leyton-Puig D, van den Berg J, Koster J, Kedziora $\mathrm{KM}$, et al. Glycerophosphodiesterase GDE2 promotes neuroblastoma differentiation through glypican release and is a marker of clinical outcome. Cancer Cell (2016) 30:548-62. doi: 10.1016/j.ccell.2016.08.016

109. De Palma M, Biziato D, Petrova TV. Microenvironmental regulation of tumour angiogenesis. Nat Rev Cancer (2017) 17:457-74. doi: $10.1038 /$ nrc. 2017.51

110. Jayson GC, Hicklin DJ, Ellis LM. Antiangiogenic therapy-evolving view based on clinical trial results. Nat Rev Clin Oncol. (2012) 9:297-303. doi: $10.1038 /$ nrclinonc. 2012.8

111. Lamorte S, Ferrero S, Aschero S, Monitillo L, Bussolati B, Omede P, et al. Syndecan-1 promotes the angiogenic phenotype of multiple myeloma endothelial cells. Leukemia (2012) 26:1081-90. doi: 10.1038/leu.2011.290

112. Purushothaman A, Uyama T, Kobayashi F, Yamada S, Sugahara K, Rapraeger AC, et al. Heparanase-enhanced shedding of syndecan-1 by myeloma cells promotes endothelial invasion and angiogenesis. Blood (2010) 115:2449-57. doi: 10.1182/blood-2009-07-234757

113. Noguer O, Villena J, Lorita J, Vilaro S, Reina M. Syndecan-2 downregulation impairs angiogenesis in human microvascular endothelial cells. Exp Cell Res. (2009) 315:795-808. doi: 10.1016/j.yexcr.2008.11.016

114. De Rossi G, Whiteford JR. A novel role for syndecan-3 in angiogenesis. F1000Res (2013) 2:270. doi: 10.12688/f1000research.2-270.v1

115. Douglass S, Goyal A, Iozzo RV. The role of perlecan and endorepellin in the control of tumor angiogenesis and endothelial cell autophagy. Connect Tissue Res. (2015) 56:381-91. doi: 10.3109/03008207.2015.1045297

116. Goyal A, Pal N, Concannon M, Paul M, Doran M, Poluzzi C, et al. Endorepellin, the angiostatic module of perlecan, interacts with both the alpha2beta1 integrin and vascular endothelial growth factor receptor 2 (VEGFR2): a dual receptor antagonism. J Biol Chem. (2011) 286:25947-62. doi: $10.1074 /$ jbc.M111.243626

117. Disis ML. Immune regulation of cancer. J Clin Oncol. (2010) 28:4531-8. doi: 10.1200/JCO.2009.27.2146

118. Pardoll DM. The blockade of immune checkpoints in cancer immunotherapy. Nat Rev Cancer (2012) 12:252-64. doi: 10.1038/nrc3239

119. Vanneman M, Dranoff G. Combining immunotherapy and targeted therapies in cancer treatment. Nat Rev Cancer (2012) 12:237-51. doi: $10.1038 / \mathrm{nrc} 3237$

120. Feng M, Ho M. Glypican-3 antibodies: a new therapeutic target for liver cancer. FEBS Lett. (2014) 588:377-82. doi: 10.1016/j.febslet.2013.10.002

121. Haruyama Y, Kataoka H. Glypican-3 is a prognostic factor and an immunotherapeutic target in hepatocellular carcinoma. World $J$ Gastroenterol. (2016) 22:275-83. doi: 10.3748/wjg.v22.i1.275

122. Wang J, Chen L. Myeloid cells' evasion of melanoma immunity. J Invest Dermatol. (2014) 134:2675-7. doi: 10.1038/jid.2014.251

123. Chung JS, Tamura K, Cruz PD Jr, Ariizumi K. DC-HIL-expressing myelomonocytic cells are critical promoters of melanoma growth. J Invest Dermatol. (2014) 134:2784-94. doi: 10.1038/jid.2014.254

124. Kruse PH, Matta J, Ugolini S, Vivier E. Natural cytotoxicity receptors and their ligands. Immunol Cell Biol. (2014) 92:221-9. doi: 10.1038/icb.2013.98

125. Hecht ML, Rosental B, Horlacher T, Hershkovitz O, De Paz JL, Noti C, et al. Natural cytotoxicity receptors NKp30, NKp44 and NKp46 bind to different heparan sulfate/heparin sequences. J Proteome Res. (2009) 8:71220. doi: $10.1021 / \mathrm{pr} 800747 \mathrm{c}$

126. Mayes K, Elsayed Z, Alhazmi A, Waters M, Alkhatib SG, Roberts $M$, et al. BPTF inhibits NK cell activity and the abundance of natural cytotoxicity receptor co-ligands. Oncotarget (2017) 8:64344-57. doi: 10.18632/oncotarget.17834

127. Kreuger J, Kjellen L. Heparan sulfate biosynthesis: regulation and variability. J Histochem Cytochem. (2012) 60:898-907. doi: 10.1369/00221554124 64972

128. Fernandez-Vega I, Garcia-Suarez O, Garcia B, Crespo A, Astudillo A, Quiros LM. Heparan sulfate proteoglycans undergo differential expression alterations in right sided colorectal cancer, depending on their metastatic character. BMC Cancer (2015) 15:742. doi: 10.1186/s12885-0151724-9

129. Jang B, Jung H, Chung H, Moon BI, Oh ES. Syndecan-2 enhances E-cadherin shedding and fibroblast-like morphological changes by inducing MMP-7 expression in colon cancer cells. Biochem Biophys Res Commun. (2016) 477:47-53. doi: 10.1016/j.bbrc.2016.06.019

130. Yang N, Friedl A. Syndecan-1-induced ECM fiber alignment requires integrin $\alpha v \beta 3$ and syndecan-1 ectodomain and heparan sulfate chains. PLoS ONE (2016) 11:e0150132. doi: 10.1371/journal.pone.0150132

131. Chakraborty S, Njah K, Pobbati AV, Lim YB, Raju A, Lakshmanan M, et al. Agrin as a mechanotransduction signal regulating YAP through the Hippo Pathway. Cell Rep. (2017) 18:2464-79. doi: 10.1016/j.celrep.2017. 02.041

132. Kalluri R. Basement membranes: structure, assembly and role in tumour angiogenesis. Nat Rev Cancer (2003) 3:422-33. doi: 10.1038/ nrc1094

133. Kawahara R, Granato DC, Carnielli CM, Cervigne NK, Oliveria CE, Rivera C, et al. Agrin and perlecan mediate tumorigenic processes in oral squamous cell carcinoma. PLoS ONE (2014) 9:e115004. doi: 10.1371/journal.pone.0115004

134. Sharma B, Handler M, Eichstetter I, Whitelock JM, Nugent MA, Iozzo RV. Antisense targeting of perlecan blocks tumor growth and angiogenesis in vivo. J Clin Invest. (1998) 102:1599-608. doi: 10.1172/JCI3793

135. Harisi R, Dudas J, Timar F, Pogany G, Timar J, Kovalszky I, et al. Invasive growth and topoisomerase-switch induced by tumorous extracellular matrix in osteosarcoma cell culture. Cell Biol Int. (2005) 29:959-67. doi: 10.1016/j.cellbi.2005.08.010

136. Zheng X, Gai X, Han S, Moser CD, Hu C, Shire AM, et al. The human sulfatase 2 inhibitor 2,4-disulfonylphenyl-tert-butylnitrone (OKN-007) has an antitumor effect in hepatocellular carcinoma mediated via suppression of TGFB1/SMAD2 and Hedgehog/GLI1 signaling. Genes Chromosomes Cancer. (2013) 52:225-36. doi: 10.1002/gcc.22022

137. Gao W, Kim H, Ho M. Human monoclonal antibody targeting the heparan sulfate chains of glypican-3 inhibits HGF-mediated migration and motility of hepatocellular carcinoma cells. PLoS ONE (2015) 10:e0137664. doi: 10.1371/journal.pone.0137664

138. Weissmann M, Arvatz G, Horowitz N, Feld S, Naroditsky I, Zhang $\mathrm{Y}$, et al. Heparanase-neutralizing antibodies attenuate lymphoma tumor growth and metastasis. Proc Natl Acad Sci USA. (2016) 113:704-9. doi: $10.1073 /$ pnas. 1519453113

139. Zhang YF, Tang XD, Gao JH, Fang DC, Yang SM. Heparanase: a universal immunotherapeutic target in human cancers. Drug Discov Today (2011) 16:412-7. doi: 10.1016/j.drudis.2011.02.015

140. Chen T, Tang XD, Wan Y, Chen L, Yu ST, Xiong Z, et al. HLA-A2-restricted cytotoxic $\mathrm{T}$ lymphocyte epitopes from human heparanase as novel targets for broad-spectrum tumor immunotherapy. Neoplasia (2008) 10:977-86. doi: $10.1593 /$ neo.08576

141. Baburajeev CP, Mohan CD, Rangappa S, Mason DJ, Fuchs JE, Bender A, et al. Identification of novel class of triazolo-thiadiazoles as potent inhibitors of human heparanase and their anticancer activity. BMC Cancer (2017) 17:235. doi: 10.1186/s12885-017-3214-8

142. Foglieni C, Pagano K, Lessi M, Bugatti A, Moroni E, Pinessi D, et al. Integrating computational and chemical biology tools in the discovery of antiangiogenic small molecule ligands of FGF2 derived from endogenous inhibitors. Sci Rep. (2016) 6:23432. doi: 10.1038/srep23432

143. Saez B, Ferraro F, Yusuf RZ, Cook CM, Yu VW, Pardo-Saganta A, et al. Inhibiting stromal cell heparan sulfate synthesis improves stem cell mobilization and enables engraftment without cytotoxic conditioning. Blood (2014) 124:2937-47. doi: 10.1182/blood-2014-08-593426

144. Brennan TV, Lin L, Brandstadter JD, Rendell VR, Dredge K, Huang $\mathrm{X}$, et al. Heparan sulfate mimetic PG545-mediated antilymphoma effects require TLR9-dependent NK cell activation. J Clin Invest. (2016) 126:207-19. doi: 10.1172/JCI76566

145. Jung DB, Yun M, Kim EO, Kim J, Kim B, Jung JH, et al. The heparan sulfate mimetic PG545 interferes with Wnt/beta-catenin signaling and significantly suppresses pancreatic tumorigenesis alone and in combination with gemcitabine. Oncotarget (2015) 6:4992-5004. doi: 10.18632/oncotarget.3214

146. Gao W, Tang Z, Zhang YF, Feng M, Qian M, Dimitrov DS, et al. Immunotoxin targeting glypican-3 regresses liver cancer via dual inhibition of Wnt signalling and protein synthesis. Nat Commun. (2015) 6:6536. doi: $10.1038 /$ ncomms7536 
147. Li N, Fu H, Hewitt SM, Dimitrov DS, Ho M. Therapeutically targeting glypican-2 via single-domain antibody-based chimeric antigen receptors and immunotoxins in neuroblastoma. Proc Natl Acad Sci USA. (2017) 114:E6623-E31. doi: 10.1073/pnas.1706055114

148. Bosse KR, Raman P, Zhu Z, Lane M, Martinez D, Heitzeneder S, et al. Identification of GPC2 as an oncoprotein and candidate immunotherapeutic target in high-risk neuroblastoma. Cancer Cell (2017) 32:295-309.e12. doi: 10.1016/j.ccell.2017.08.003

149. Christianson HC, Belting M. Heparan sulfate proteoglycan as a cell-surface endocytosis receptor. Matrix Biol. (2014) 35:51-5. doi: 10.1016/j.matbio.2013.10.004

150. Fares J, Kashyap R, Zimmermann P. Syntenin: key player in cancer exosome biogenesis and uptake? Cell Adh Migr. (2017) 11:124-6. doi: 10.1080/19336918.2016.1225632

151. Friand V, David G, Zimmermann P. Syntenin and syndecan in the biogenesis of exosomes. Biol Cell (2015) 107:331-41. doi: 10.1111/boc.201 500010

152. Granes F, Berndt C, Roy C, Mangeat P, Reina M, Vilaro S. Identification of a novel Ezrin-binding site in syndecan-2 cytoplasmic domain. FEBS Lett. (2003) 547:212-6. doi: 10.1016/S0014-5793(03)00712-9
153. Kasza I, Suh Y, Wollny D, Clark RJ, Roopra A, Colman RJ, et al. Syndecan-1 is required to maintain intradermal fat and prevent cold stress. PLoS Genet. (2014) 10:e1004514. doi: 10.1371/journal.pgen.1004514

154. Menard JA, Christianson HC, Kucharzewska P, Bourseau-Guilmain E, Svensson KJ, Lindqvist E, et al. Metastasis stimulation by hypoxia and acidosis-induced extracellular lipid uptake is mediated by proteoglycan-dependent endocytosis. Cancer Res. (2016) 76:4828-40. doi: 10.1158/0008-5472.CAN-15-2831

Conflict of Interest Statement: The authors declare that the research was conducted in the absence of any commercial or financial relationships that could be construed as a potential conflict of interest.

Copyright (c) 2018 Nagarajan, Malvi and Wajapeyee. This is an open-access article distributed under the terms of the Creative Commons Attribution License (CC BY). The use, distribution or reproduction in other forums is permitted, provided the original author(s) and the copyright owner(s) are credited and that the original publication in this journal is cited, in accordance with accepted academic practice. No use, distribution or reproduction is permitted which does not comply with these terms. 